\title{
Binge drinking and overweight in brazilian adults - CUME Project
}

\author{
Consumo pesado episódico de álcool e excesso de peso em adultos brasileiros - Projeto CUME \\ Borrachera y sobrepeso en adultos brasileños - Proyecto CUME
}

Luís Paulo Souza e Souza',1,,III ORCID: 0000-0002-9801-4157

Aline Elizabeth da Silva Miranda ORCID: 0000-0001-9826-1409

Helen Hermana Miranda Hermsdorff'v ORCID: 0000-0002-4441-6572

Carla Silvana de Oliveira e Silva"I ORCID: 0000-0002-2752-1557

Dulce Aparecida Barbosav ORCID: 0000-0002-9912-4446

Josefina Bressan ${ }^{\text {iv }}$ ORCID: 0000-0002-4993-9436 Adriano Marçal Pimenta' ORCID: 0000-0001-7049-7575

Universidade Federal de Minas Gerais. Belo Horizonte, Minas Gerais, Brazil. "Universidade Federal do Amazonas. Coari, Amazonas, Brazil. I"Universidade Estadual de Montes Claros. Montes Claros, Minas Gerais, Brazil.

"Universidade Federal de Viçosa. Viçosa, Minas Gerais, Brazil.

$\checkmark$ Universidade Federal de São Paulo. São Paulo, São Paulo, Brazil.

How to cite this article: Souza e Souza LP, Miranda AES, Hermsdorff HHM Silva CSO, Barbosa DA, Bressan J, et al. Binge drinking and overweight in brazilian adults - CUME Project.

Rev Bras Enferm. 2020;73(Suppl 1):e20190316 doi: http://dx.doi.org/10.1590/0034-7167-2019-0316

Corresponding author:

Luís Paulo Souza e Souza

E-mail: luis.pauloss@hotmail.com

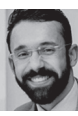

EDITOR IN CHIEF: Antonio José de Almeida Filho ASSOCIATE EDITOR: Hugo Fernandes

\section{ABSTRACT}

Objective: To verify the association between heavy episodic alcohol consumption [binge drinking (BD)] and overweight in 2,909 adults from the Cohort of Universities of Minas Gerais (CUME Project) baseline, Brazil. Method: Cross-sectional study in which sociodemographic anthropometric (BMI $\geq 25 \mathrm{~kg} / \mathrm{m}^{2}$ = overweight) and dietary intake data were collected. This study evaluated the occurrence and monthly frequency of $\mathrm{BD}$ ( $\geq 4$ drinks at one time for women; $\geq 5$ drinks at one time for men, in the last 30 days). Results: The prevalence of $B D$ and overweight were $41.3 \%$ and $40.8 \%$, respectively. BD increased the prevalence of overweight by $19 \%$, and, BD exposure by $\geq 5$ days / month increased it by $31 \%$. Conclusion: BD on a single or multiple occasion during the month was associated with a higher prevalence of overweight Therefore, such a lifestyle should be considered in weight gain prevention strategies. Descriptors: Binge Drinking; Alcoholic Beverages; Food Consumption; Overweight; Obesity.

\section{RESUMO}

Objetivo: Verificar associação entre consumo pesado episódico de álcool [binge drinking (BD)] e excesso de peso em 2.909 adultos da linha de base da Coorte de Universidades Mineiras (CUME), Brasil. Método: Estudo transversal no qual se coletaram dados sociodemográficos, antropométricos (IMC $\geq 25 \mathrm{~kg} / \mathrm{m}^{2}=$ excesso de peso) e alimentares. Avaliaram-se presença e frequência mensal do $B D$ ( $\geq 4$ doses em única ocasião para mulheres; $\geq 5$ doses para homens, nos últimos 30 dias). Resultados: As prevalências do BD e excesso de peso foram $41,3 \%$ e $40,8 \%$, respectivamente. O BD aumentou em $19 \%$ a prevalência do excesso de peso, e a exposição ao $\mathrm{BD}$ em $\geq 5$ dias/mês aumentou em $31 \%$. Conclusão: $\mathrm{O}$ BD em única ou em várias ocasiões no mês se associou à maior prevalência de excesso de peso. Portanto, tal hábito de vida deve ser considerado nas estratégias de prevenção do ganho de peso.

Descritores: Bebedeira; Bebidas Alcoólicas; Consumo Alimentar; Sobrepeso; Obesidade.

\section{RESUMEN}

Objetivo: Verificar la relación entre el episodio de exceso de alcohol [binge drinking (BD)] y el sobrepeso en 2.909 adultos de la línea de base de la Coorte de Universidades Mineiras (CUME), Brasil. Método: Estudio transversal en lo cual se recogieron datos sociodemográficos, antropométricos (IMC $\geq 25 \mathrm{~kg} / \mathrm{m}^{2}=$ sobrepeso) y alimentares. Se evaluaron presencia y frecuencia mensual del $\mathrm{BD}$ ( $\geq 4$ dosis en única ocasión para mujeres; $\geq 5$ dosis para hombres, en los últimos 30 días). Resultados: Las prevalencias del BD y sobrepeso han sido $41,3 \%$ y $40,8 \%$, respectivamente. BD ha aumentado en $19 \%$ la prevalencia del sobrepeso, y la exposición al BD en $\geq 5$ días/mes ha aumentado en $31 \%$. Conclusión: El BD en única o en varias ocasiones en el mes se relacionó a la mayor prevalencia de sobrepeso. Así que, tal hábito de vida debe ser considerado en las estrategias de prevención del aumento de peso.

Descriptores: Borrachera; Bebidas Alcohólicas; Consumo de Alimentos; Sobrepeso; Obesidad. 
Binge drinking and overweight in brazilian adults - CUME Project Souza e Souza LP, Miranda AES, Hermsdorff HHM, Silva CSO, Barbosa DA, Bressan J, et al.

\section{INTRODUCTION}

Alcohol consumption has become a global problem, given its increase among the adult population. The World Health Organization indicates that the global consumption of pure alcohol is around 6.4 liters per person older than 15. In Brazil, the average consumption is 8.9 liters per person, placing the country in the 49th position of the ranking among the 193 countries considered in the analysis ${ }^{(1)}$.

Assessing the impact that this consumption has on communities, it is estimated that 2.8 million deaths were attributed to alcohol in 2016 , corresponding to $2.2 \%$ of deaths among women and $6.8 \%$ among men. Worldwide, alcohol consumption has been ranked as the seventh leading risk factor for premature death and disability ${ }^{(2)}$. In addition, the alcohol intake increases the risk of noncommunicable diseases (NDs), such as cardiovascular diseases, cirrhosis, cancers, overweight, traffic accidents and violence ${ }^{(1)}$.

Because it is a food, alcohol presents kilocalories; and due to its energy value, it is presumed to have the potential to suppress daily caloric needs of an individual and also lead him do overweight, depending on frequency, mode of consumption and quantity ${ }^{(3-4)}$. However, authors emphasize that the role of alcohol as a potential factor for weight gain has been overlooked in the scientific literature ${ }^{(4-5)}$.

More recently published studies show that abusive alcohol consumption (not including alcohol dependence) increases the risk for overweight in both genders ${ }^{(3-6)}$.

Some definitions to evaluate alcohol abuse have been proposed, but one of the most commonly used is "heavy episodic consumption" (binge drinking - BD), characterized by the ingestion of 4 or more doses of alcohol on a single occasion for women, and 5 or more for men, in the last 30 days $^{(7)}$. It is estimated that worldwide $17.1 \%$ of the population is exposed to the $\mathrm{BD}^{(8)}$ standard, whereas in Brazil the proportion of this habit is $17.9 \%{ }^{(9)}$.

Studies show a strong association between BD and overweight $^{(4-5,10)}$, however they do not evaluate whether this relationship is influenced by higher monthly exposure to BD. It is believed that greater exposure to $\mathrm{BD}$ is one of the factors that further favors weight gain.

It is noteworthy that being overweight is the largest nutritional disorder today, with a worldwide prevalence of $39 \%$ and related countries' expenses ranging from $1 \%$ to $3 \%$ of total costs in the health sector ${ }^{(11)}$. In Brazil, it is estimated that $55.7 \%$ of the adult population is overweight ${ }^{(9)}$.

Therefore, given that both BD and overweight are of interest to public health due to their high magnitudes and because they are both considered as important risk factors for NDs, it is necessary to better understand the association between these diseases ${ }^{(5)}$, especially in Brazilian adults, as it is one of the populations that most consume alcoholic beverages in the world ${ }^{(1)}$.

\section{OBJECTIVE}

To verify the association between heavy episodic alcohol consumption (BD) and overweight in 2,909 adults from the Cohort of Universities of Minas Gerais (CUME) baseline, Brazil.

\section{METHOD}

\section{Ethical aspects}

The CUME Project was approved by the Human Research Ethics Committees in Research of the Federal University of Viçosa (UFV) and the Federal University of Minas Gerais (UFMG). All participants read and agreed to the online free and informed consent form.

\section{Study Design, location, and period}

This is a baseline analysis of the Cohort of Universities of Minas Gerais, which is an open and restricted population cohort, whose objective is to evaluate the impact of the Brazilian dietary pattern and nutritional transition on NDs in students of Federal Institutions of Higher Education, located in the state of Minas Gerais, Brazil. The design, dissemination strategies employed, and project baseline profile were detailed in a previous publication ${ }^{(12)}$. It is noteworthy this article used the Strengthening the Reporting of Observational Studies in Epidemiology (STROBE) to guide its methodology ${ }^{(13)}$.

The study initiated its baseline with graduates, from 1994 to 2014, from UFV and UFMG. Data collection took place between March and August 2016, in a virtual environment of the CUME Project.

\section{Population or sample; inclusion and exclusion criteria}

Invitations to participate in the research were sent to all 64,202 UFMG alumni and 16,945 UFV alumni graduated during the indicated period (undergraduates and postgraduates), whose e-mails were included in the alumni associations' databases or in the Technology and Information Directorates of Universities. 3,270 participants responded to the baseline questionnaire $\left(\mathrm{Q} \_0\right)$, being excluded those who reported inconsistent values for total calorie consumption $[<500 \mathrm{kcal} /$ day $(\mathrm{n}=$ 1) or $>6,000 \mathrm{kcal} /$ day $(n=92)]^{(14)}$, pregnant women and, women who had children in the last year $(n=123)$. In addition, considering the overall objective of the cohort, participants from other nationalities ( $n=11)$ and Brazilians living abroad $(n=134)$ were also excluded. Thus, the final sample consisted of 2,909 participants.

\section{Study Protocol}

For data collection, a self-administered baseline online questionnaire (Q_0) was used and, due to its extension, it was divided into two parts (access at: http://www.projetocume.com.br/questionario). The first part consisted of questions related to sociodemographic and economic characteristics, lifestyle, individual and family referred morbidity, medication use, personal history of clinical and biochemical examinations of the last two years and anthropometric data. The second part of the instrument was sent 1 week after the conclusion of the first part and had a Food Frequency Questionnaire (FFQ) composed of a set of 144 food items, based on the original version previously validated in $\mathrm{Brazi}^{(15)}$.

The outcome variable used for the analyzes in this article was "overweight," based on self-reported weight $(\mathrm{kg})$ and height $(\mathrm{cm})$ data, and Body Mass Index (BMI) was calculated. Thus, people were classified in two ways regarding overweight (BMI $<25.0 \mathrm{~kg} /$ $\mathrm{m}^{2}=$ no overweight; $\mathrm{BMI} \geq 25.0 \mathrm{~kg} / \mathrm{m}^{2}=$ overweight). 
The self-reported data on weight, height and BMI were previously validated, obtaining intraclass correlation coefficients, indicating excellent agreement: 0.989 (weight), 0.955 (height) and 0.893 (BMI) $^{(16)}$.

The exposure variable in this study was BD, determined by consumption of 4 drinks or more (beer, wine and / or spirits) at one time for women and 5 or more for men, in the last 30 days ${ }^{(7)}$, with such exposure evaluated dichotomously (no, yes) and according to its monthly frequency (no day/month, 1-2 days/month, 3-4 days/month, $\geq 5$ days/month).

As adjustment variables, we used the participants' sociodemographic, lifestyle, food consumption and clinical conditions.

The sociodemographic variables evaluated were: gender (male, female); age (years - continuous); skin color (white, black/brown, yellow/indigenous); marital status (single, legally married/stable union/other, separated or divorced/widowed); professional status (retired/ work at home/unemployed, student, full-time work, parttime work, informal work) and family income (continuous).

Regarding lifestyle, the following were evaluated: smoking habit (never smoker, former smoker and current smoker); and physical activity, evaluated through a list of 24 activities and expressed in minutes per week (active $=$ individuals with $\geq 150$ minutes / week of moderate intensity activity or $\geq 75$ minutes / week of vigorous intensity activity; insufficiently active $=$ individuals with $<150$ minutes / week of moderate intensity activity or $<75$ minutes / week of vigorous intensity activity; inactive $=$ no physical activity at leisure time $)^{(17)}$.

Information on food consumption was taken from the FFQ. Due to the auto-filling and the online format of the instrument, it was necessary to provide images of food items and utensils to assist in estimating portion size and filling, and in addition to obtain a reliable answer regarding the participants'consumption ${ }^{(18)}$. At the beginning of each page the questionnaire presented a list of items that constituted the food group, and the participant was instructed to select the foods consumed in the previous year. For each selected food, the participant indicated the portion size expressed in household measures commonly used in Brazil (teaspoon, tablespoon, ladle, knife tip, gripper, saucer, cup and glass) or in traditional food portions ( unit, slices and pieces) and the usual frequency of consumption (day/week/month / year).

The intake frequencies of each food were transformed into daily consumption. Subsequently, we calculated the daily food intake (grams or milliliters) by multiplying the portion size by the frequency of consumption. To calculate caloric intake (kcal) and nutrients, we used Brazilian food composition tables ${ }^{(19)}$ and, if necessary, the United States Department of Agriculture Food Composition Databases ${ }^{(20)}$. In addition, food items were characterized according to the NOVA food classification as minimally processed, processed and ultra-processed ${ }^{(21)}$.

Macronutrients, minimally processed, processed and ultraprocessed foods were represented by the percentage (\%) of calories / day in the diet. Daily nutrient intake was adjusted for caloric intake using the residual method ${ }^{(22)}$, prior to statistical analysis.

Clinical variables were obtained from questions if the participant had already received the medical diagnosis, that is, confirmation by a medical professional, for each of the following diseases: stroke, infarction, celiac disease, inflammatory bowel disease [Crohn, rectocolitis ulcerative disease], nonalcoholic liver steatosis, alcoholic cirrhosis, gastritis, gastric or duodenal ulcer, acute renal failure, chronic renal failure, lung cancer, skin cancer, colon cancer, breast cancer, cervical cancer, cancer prostate cancer, diabetes mellitus type 2, systemic arterial hypertension, high triglycerides, high cholesterol, depression (no, yes)

\section{Results analysis and statistics}

Participants were characterized by absolute and relative frequencies, means and standard deviations of the following variables sociodemographic, lifestyle, anthropometric, food consumption and medical diagnosis of diseases, according to the monthly frequency of exposure to BD.

Prevalence ratios $(\mathrm{PR})$ and their respective confidence intervals $(\mathrm{Cl}$ [95\%]) of associations between exposure variable and overweight were estimated using Poisson regression models with robust variances, which were adjusted for sex and age and, subsequently, by all other adjustment variables mentioned above. Also, for the monthly frequency of $\mathrm{BD}$, a linear trend evaluation test was conducted, introducing the variable as continuous in Poisson multivariate regression models.

Sensitivity analyzes were performed to assess the robustness of the results of this study, excluding: (a) people with a previous medical diagnosis of obesity, (b) people who gained 10 kilograms or more prior to the study, (c) all people considered in analyzes (a) and (b), in addition to those using weight control medication.

All analyzes were performed using the Stata statistical software, version 13.0, at a significance level of $5 \%$.

\section{RESULTS}

Of the total participants, $40.8 \%(n=1,188)$ were overweight, i.e., $27.6 \%(n=804)$ were overweight and $13.2 \%(n=384)$ were obese. In addition, 3.0\% $(n=87)$ were underweight and 56.2\% $(n=1,634)$ were eutrophic. Regarding the pattern of alcohol consumption, $41.3 \%$ ( $n=1,203)$ of the participants reported BD, and among them, the highest frequency of exposure to such habit reported was 1 to 2 days / month (52.7\%), followed by by those who were exposed from 3 to 4 days / month (27.9\%) and 5 or more days / month (19.4\%).

Of the participants who were overweight, $45.8 \%(n=544)$ drank alcoholic beverages in the BD standard, this proportion being significantly higher than that observed for individuals without overweight $(37.8 \% ; n=644)(p<0.001)$.

Table 1 presents the sociodemographic characteristics of the participants according to the frequency of exposure to the BD. Compared to participants who did not drink alcoholics beverages in the BD standard, those who drank 5 or more days / month were more often male, single, with a lower average age and higher average household income $(p<0,05)$.

Table 2 presents the characteristics of the participants'lifestyle, anthropometry, food consumption and medical diagnosis of disease according to the frequency of exposure to BD. Compared to participants who did not drink alcohol beverages in the BD standard, those who drank 5 or more days/month were more often current smokers, physically active, overweight, with higher averages of alcohol consumption and polyunsaturated fat, and monounsaturated fat consumption and lower average lipid, trans fat and minimally processed foods intakes. Participants more exposed to BD had a lower proportion of diagnoses of chronic diseases than those not exposed to this pattern of alcohol consumption $(p<0.05)$. 
Table 1 - Sociodemographic characteristics of participants according to monthly frequency of exposure to binge drinking, cohort of Universities of Minas Gerais (CUME), Brazil, 2016

\begin{tabular}{|c|c|c|c|c|c|c|c|c|c|c|c|}
\hline \multirow{3}{*}{ Variables } & \multirow{2}{*}{\multicolumn{2}{|c|}{$\begin{array}{c}\text { Total } \\
(n=2,909)\end{array}$}} & \multicolumn{8}{|c|}{ Monthly frequency of binge drinking } & \multirow{3}{*}{$p$ value* } \\
\hline & & & \multicolumn{2}{|c|}{$\begin{array}{l}\text { No Day / Month } \\
(n=1,706)\end{array}$} & \multicolumn{2}{|c|}{$\begin{array}{l}\text { 1-2 days / month } \\
(n=634)\end{array}$} & \multicolumn{2}{|c|}{$\begin{array}{l}\text { 3-4 days / month } \\
(n=336)\end{array}$} & \multicolumn{2}{|c|}{$\begin{array}{c}\geq 5 \text { days / month } \\
(n=233)\end{array}$} & \\
\hline & $\mathbf{n}$ & $\%$ & $\mathbf{n}$ & $\%$ & $\mathbf{n}$ & $\%$ & $\mathbf{n}$ & $\%$ & $\mathbf{N}$ & $\%$ & \\
\hline Gender & & & & & & & & & & & $<0.001$ \\
\hline Male & 909 & 31.3 & 450 & 26.4 & 201 & 31.7 & 147 & 43.7 & 111 & 47.6 & \\
\hline Age (years) ${ }^{* *}$ & \multicolumn{2}{|c|}{$36.3(9.5)$} & \multicolumn{2}{|c|}{$36.9(10.0)$} & \multicolumn{2}{|c|}{$34.8(8.3)$} & \multicolumn{2}{|c|}{$36.1(9.8)$} & \multicolumn{2}{|c|}{$35.5(8.5)$} & $<0.001$ \\
\hline \multicolumn{11}{|l|}{ Skin color } & 0.364 \\
\hline White & 1,896 & 65.2 & 1,112 & 65.2 & 406 & 64.0 & 213 & 63.4 & 165 & 70.8 & \\
\hline Black / Brown & 984 & 33.8 & 573 & 33.6 & 223 & 35.2 & 121 & 36.0 & 67 & 28.8 & \\
\hline Yellow / Indigenous & 29 & 1 & 21 & 1.2 & 5 & 0.8 & 2 & 0.6 & 1 & 0.4 & \\
\hline \multicolumn{11}{|l|}{ Marital Status } & 0.012 \\
\hline Single & 1,276 & 43.9 & 699 & 40.9 & 304 & 48.0 & 157 & 46.7 & 116 & 49.8 & \\
\hline Legally married / Stable Union & 1,465 & 50.4 & 897 & 52.6 & 302 & 47.6 & 162 & 48.2 & 104 & 44.6 & \\
\hline Separated or divorced / Widow/widowe & 168 & 5.7 & 110 & 6.5 & 28 & 4.4 & 17 & 5.1 & 13 & 5.6 & \\
\hline \multicolumn{11}{|l|}{ Professional status } & 0.041 \\
\hline Retired / work at home / Unemployed & 235 & 8.1 & 155 & 9.1 & 43 & 6.8 & 22 & 6.5 & 15 & 6.4 & \\
\hline Student & 382 & 13.1 & 217 & 12.7 & 91 & 14.4 & 40 & 12.0 & 34 & 14.6 & \\
\hline Full-time work & 1,857 & 63.8 & 1,052 & 61.7 & 416 & 65.6 & 229 & 68.2 & 160 & 68.7 & \\
\hline Part-time work & 358 & 12.3 & 236 & 13.8 & 70 & 11.0 & 36 & 10.7 & 16 & 6.9 & \\
\hline Informal work & 77 & 2.7 & 46 & 2.7 & 14 & 2.2 & 9 & 2.6 & 8 & 3.4 & \\
\hline Family Income $(\mathrm{R} \$)^{* *}$ & \multicolumn{2}{|c|}{$8.758(6.901)$} & \multicolumn{2}{|c|}{$8.447(6.802)$} & \multicolumn{2}{|c|}{$8.934(6.791)$} & \multicolumn{2}{|c|}{$9.360(7.307)$} & \multicolumn{2}{|c|}{9.688 (7.196) } & 0.013 \\
\hline
\end{tabular}

Table 2 - Characteristics of participants'lifestyle, anthropometry, food consumption, and medical diagnosis of disease according to the monthly frequency of exposure to the binge drinking, cohort of Universities of Minas Gerais (CUME), Brazil, 2016

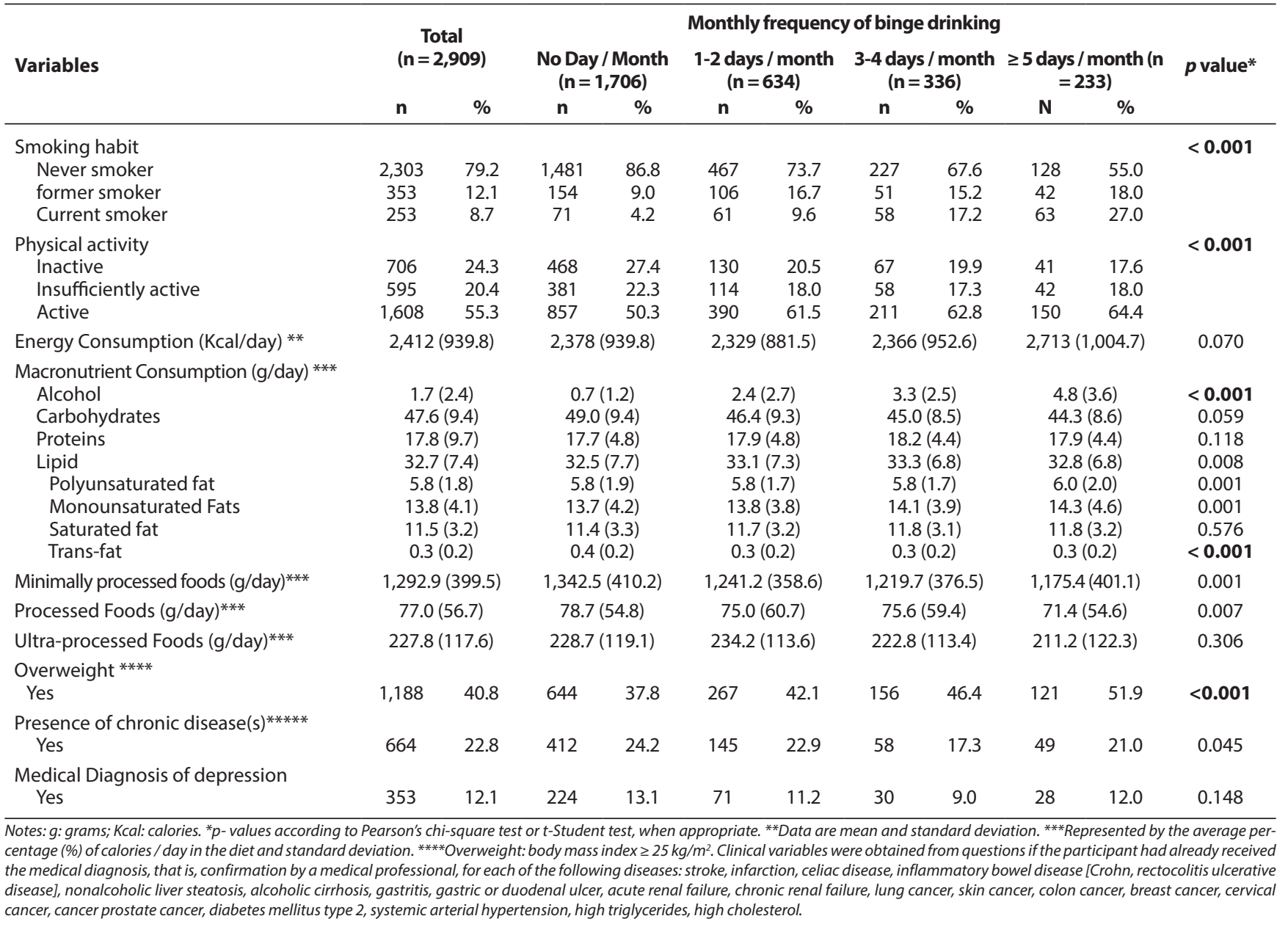


Table 3 - Prevalence Ratio and 95\% Confidence Interval for the association between binge drinking standard and overweight, cohort of Universities of Minas Gerais (CUME), Brazil, 2016

\begin{tabular}{|c|c|c|c|c|}
\hline \multirow{2}{*}{ Variables } & \multicolumn{2}{|c|}{ Gross analysis } & \multicolumn{2}{|c|}{ Adjusted Analysis } \\
\hline & PR (95\% Cl) & $p$ value & PR (95\% Cl) & $p$ value \\
\hline \multicolumn{5}{|l|}{ Binge drinking* } \\
\hline No $(n=644)$ & 1.00 & - & 1.00 & - \\
\hline Yes $(n=544)$ & $1.20(1.10-1.31)$ & $<0.001$ & $1.19(1.09-1.30)$ & $<0.001$ \\
\hline \multicolumn{5}{|c|}{ Monthly frequency of binge drinking* } \\
\hline No day / month $(n=644)$ & 1.00 & - & 1.00 & - \\
\hline $1-2$ days $/$ month $(n=267)$ & $1.11(0.99-1.24)$ & 0.051 & $1.17(1.05-1.30)$ & 0.003 \\
\hline 3-4 days / month $(n=156)$ & $1.22(1.07-1.40)$ & 0.002 & $1.16(1.02-1.31)$ & 0.022 \\
\hline$\geq 5$ days $/$ month $(n=121)$ & $1.37(1.19-1.57)$ & $<0.001$ & $1.31(1.14-1.51)$ & $<0.001$ \\
\hline plinear trend & & $<0.001$ & & $<0.001$ \\
\hline
\end{tabular}

Note: PR: Prevalence Ratio; CI: 95\% Confidence Interval; *Analysis adjusted by gender; age; color; marital status; professional status; smoking habit; physical activity; medical diagnosis of depression; family income.

Table 4 - Sensitivity analysis of Prevalence Ratio and 95\% Confidence Intervals for the association between binge drinking and overweight, CUME Project, Brazil, 2016

\begin{tabular}{|c|c|c|c|}
\hline \multirow[b]{2}{*}{ Variables } & \multicolumn{3}{|c|}{ Sensitivity Analysis } \\
\hline & $\begin{array}{c}\text { Analysis } 1 \\
(\mathrm{n}=2,653) \\
\mathrm{PR}(95 \% \mathrm{Cl})\end{array}$ & $\begin{array}{c}\text { Analysis } 2 \\
(\mathrm{n}=2,706) \\
\text { PR }(95 \% \mathrm{Cl})\end{array}$ & $\begin{array}{c}\text { Analysis } 3 \\
(\mathrm{n}=2,489) \\
\mathrm{PR}(95 \% \mathrm{Cl})\end{array}$ \\
\hline \multicolumn{4}{|l|}{ Binge drinking* } \\
\hline No $(n=644)$ & 1.00 & 1.00 & 1.00 \\
\hline Yes $(n=544)$ & $1.23(1.12-1.36)$ & $1.23(1.11-1.36)$ & $1.29(1.12-1.49)$ \\
\hline \multicolumn{4}{|c|}{ Monthly frequency of binge drinking* } \\
\hline No day / month $(n=644)$ & 1.00 & 1.00 & 1.00 \\
\hline $1-2$ days $/$ month $(n=267)$ & $1.21(1.07-1.37)$ & $1.22(1.09-1.37)$ & $1.29(1.13-1.47)$ \\
\hline 3-4 days $/$ month $(n=156)$ & $1.18(1.02-1.37)$ & $1.16(1.00-1.34)$ & $1.18(1.00-1.39)$ \\
\hline$\geq 5$ days $/$ month $(n=121)$ & $1.40(1.20-1.64)$ & $1.37(1.17-1.60)$ & $1.48(1.24-1.77)$ \\
\hline$p$ linear trend & $<0.001$ & $<0.001$ & $<0.001$ \\
\hline
\end{tabular}

Notes: PR: Prevalence Ratio; Cl: 95\% Confidence Interval. Analysis 1: Exclusion of people with previous medical diagnosis of obesity $(n=256)$. Analysis 2: Exclusion of people who gained 10 or more kilograms prior to the study $(n=203)$. Analysis 3: Exclusion of all persons considered in analyzes 1 and $2(n=408)$, in addition to those who used weight control medication $(n=12)$ (total $=420$ ). ${ }^{*}$ Analysis adjusted by gender; age; color; marital status; professional status; smoking habit; physical activity; medical diagnosis of depression; family income.

Table 3 shows the results of the multivariate analysis, indicating that $\mathrm{BD}$ increased the prevalence of overweight by $19 \%$ regardless of confounders. The monthly frequency of BD was positively associated with the prevalence of overweight ( $p$ trend $<0.001$ ), being the strength of this association higher among those who maintained this habit 5 or more days / month (PR: 1.31; Cl 95\%: 1.14-1.51).

Table 4 presents the sensitivity analyzes, showing that when we excluded: 1) participants with previous medical diagnosis of obesity ( $n=256)$; 2 ) participants who gained 10 or more kilograms prior to the study $(n=203)$; or 3 ) the combination of the two criteria + participants who used weight-loss drugs $(n=$ 420), in all sensitivity analyzes, BD was positively associated with overweight, also maintaining increased prevalence of the outcome with increased monthly frequency of exposure $(p \leq 0.001)$.

\section{DISCUSSION}

In the present study, we evidenced a high proportion of participants who indicated the BD pattern of alcohol consumption, as well as a positive association between repeated monthly exposures to this habit and overweight. Such relationship is an original finding of this investigation, since, to our knowledge, it has not been explored in adults in the literature so far.

In this study, $41.3 \%$ of participants reported exposure to BD, a proportion much higher than that observed for the Brazilian adult population (17.9\%) according to the survey "Surveillance System for Risk and Protective Factors for Chronic Diseases by Telephone Survey" (Vigitel - Vigilância de Fatores de Risco e Proteção para Doenças Crônicas por Inquérito Telefônico) ${ }^{(9)}$; it is also higher than other international surveys ${ }^{(22-25)}$.

The differences in BD frequencies observed in this study compared to those evidenced in other national and international surveys can be explained by the fact that CUME participants have high income and high education, factors related to high alcohol intake ${ }^{(25)}$. The literature points out that higher income levels and years of study facilitate the purchase of alcoholic beverages and contribute to a more active social life, because of the presence of this substance in work meetings or even by the stress caused by these events, stimulating alcohol intake and, also high-risk consumption (BD) ${ }^{(25)}$. In Vigitel ${ }^{(9)}$, BD frequency tended to increase with schooling levels; and in studies in Israel ${ }^{(25)}$ and in Italy ${ }^{(24)}$, participants who exhibited this behavior had higher incomes, reinforcing our hypotheses.

The present study found that BD behavior remained associated with overweight in all analyzes, which is similar to what other studies found ${ }^{(3-4,7,26)}$. We also observed a trend of increasing outcome prevalence with increasing monthly frequency of BD exposure ( $p \leq 0.001)$.

As previously mentioned, it is important to highlight that studies that evaluated the effect of BD on weight gain did not analyze the monthly frequency of exposure, the distinctive aspect of this research, since exposure to this behavior 5 or more times a month increased the prevalence of overweight by up to $31 \%$. In addition, some of the studies that more succinctly assess BD and its effect on excess or weight gain were conducted with adolescents or college students, different populations from those of our research, limiting comparisons ${ }^{(27-28)}$.

As a toxic substance, alcohol becomes an energy source unlike any other, as it needs to be eliminated as soon as possible. Thus, it has priority in metabolism, altering different metabolic pathways ${ }^{(3)}$.

The main and most common pathway of metabolism of alcohol is that which uses the enzyme alcohol dehydrogenase (ADH), which oxidizes alcohol or ethanol to acetaldehyde. In excessive drinkers, because ADH activity may be blocked, there is another pathway of metabolism, the mitochondrial oxidation system of ethanol, which does not generate energy-forming components. Another pathway used in excessive drinkers and in chronic alcohol 
Binge drinking and overweight in brazilian adults - CUME Project Souza e Souza LP, Miranda AES, Hermsdorff HHM, Silva CSO, Barbosa DA, Bressan J et al.

abusers is the catalase pathway, which has a small participation in the process, because it metabolizes only $10 \%$ of the ingested alcohol, also generating no energy ${ }^{(3)}$.

Acetaldehyde is product of this three routes, which will be oxidized to acetate or acetic acid and water. At the end of metabolism, acetate is a great form of energy and inhibits lipid oxidation or fat breakage, which saves energy and can thus increase body fat and generate excess weight ${ }^{(3)}$.

Other reasons for explaining the biological plausibility of the findings are that alcohol intake stimulates appetite; alcohol is the macronutrient with the lowest satiety effect; and its consumption affects many neurotransmitters and hormonal afferent signals, leading to a possible effect on diet control ${ }^{(3)}$. Thus, the higher the exposure to heavy alcohol consumption, the more these pathways and effects will be activated and, the higher the lipid inhibition will be, as well as the caloric supply and the gain of adipose tissue.

The Global Burden of Disease-GBD 2016 Alcohol Collaborators ${ }^{(2)}$, finds alcohol harmful to health in any amount of use. Therefore, there is the need to reduce the widely accepted view that light to moderate alcohol consumption is not harmful, in order to treat this proposition with caution. People who make light use of alcoholic beverages or do not drink cannot be encouraged to expect substantial benefit from drinking. In contrast, for those who already consume them, the recommendation is moderation in use, avoiding episodes of excessive ingestion.

Of the total participants, $40.8 \%$ were overweight. Although this prevalence is high, it is lower than that found in the Brazilian adult population in general $(55.7 \%)^{(9)}$ and in other national and international surveys ${ }^{(26,29)}$; but similar to the cohort Seguimiento Universidad de Navarra (SUN) ${ }^{(30)}(38 \%)$, which presents a sample with characteristics very similar to ours.

These differences can be explained by the characteristics of the population analyzed in this study, composed mostly of young adults with high income and education, protective factors for overweight ${ }^{(30)}$. People in better socioeconomic status are more likely to adhere better to health care measures and have better access to health services, even though their alcohol consumption is higher ${ }^{(23)}$.

Behaviors and lifestyle habits are also shaped by the environment and social relationships, as groups may share preferences regarding, for example, eating habits ${ }^{(31)}$. Thus, the people analyzed here tend to live with others of the same socioeconomic position, sharing their habits and adopting the same patterns of alcohol consumption. Strategies that encourage the reduction of alcohol consumption in this population should be intensified as it is a highly modifiable factor ${ }^{(2)}$. And because these people tend to more easily correct their unhealthy habits and lifestyles ${ }^{(31)}$, public policies and health education actions must emphasize this reduction.

Another point that would fit in the discussion about the high alcohol consumption found here is about the diagnosis of depression in the sample. As much as we have controlled this variable in the analyzes, it may be possible that participants who did not report a medical diagnosis of depression were underdiagnosed or had only mild depressive episodes, underestimating their symptoms. Even though some studies show divergent results, there are consistent data pointing out that occupying high income and education positions may be a predisposing factor for anxiety or depression ${ }^{(32)}$. And because alcohol-related drinking disorders, with episodes of heavy drinking often coexist with mood disorders ${ }^{(32)}$, we raise this hypothesis.

\section{Study Limitations}

This research presents as limitations the fact that it is a crosssectional analysis, and it is not plausible to conclude causal relations. Another limitation could be self-reported alcohol consumption; however, in a community sample, where alcohol consumption is legally produced, socially accepted and perceived as part of the traditional dietary pattern, the problem of misrepresentation may be minimal ${ }^{(33)}$.

\section{Contributions to the Nursing, Health, or Public Policy Fields}

Although this study presents a different sample profile, in a better socioeconomic position, this characteristic allowed it do be more detailed and provide further development in the questions of the questionnaire. Similar sample research has shown very reliable and valid results and high retention rate ${ }^{(30)}$. The inclusion of people with high economic and educational level is important to provide more reliable exposure data and outcomes, and to verify how these individuals behave over time.

Specifically for Nursing, because it brings new data for the Brazilian context, this study provides the contribution of highlighting the need for nurses to center in the care of noncommunicable diseases "the influence alcohol abuse has on overweight". The growth of NCDs brings a new focus to the trainning of nurses, that needs to provide qualification on solid and directed bases that consider new aspects in the process of determining illness and health conditions.

\section{CONCLUSION}

Finally, this study concluded that the prevalence of the BD pattern was high and the monthly frequency of such exposure was associated with a higher prevalence of overweight. Therefore, it is of utmost importance to emphasize to the population that not only daily or weekly alcohol use is harmful, but also that heavy drinking on a single or multiple occasions in the month poses even greater risks to weight gain. Thus, it is essential to discuss, in strategies for prevention and control of overweight, the exposure to the BD standard.

\section{FUNDING}

Research Support Foundation of Minas Gerais (FAPEMIG - Fundação de Amparo à Pesquisa de Minas Gerais), processes CDS-APQ-00571/13, CDS-APQ-02407/16, CDS-APQ-00424/17.

\section{ACKNOWLEDGEMENTS}

To participants in the Cohort of Universities of Minas Gerais (CUME), as well as the Coordination of Support to Higher Level Personnel (CAPES - Coordenação de Aperfeiçoamento de Pessoal de Nível Superior) (Ministry of Education - Ministério da Educação, funding code 001) and the Research Support Foundation of Minas Gerais (FAPEMIG) for financial support. 


\section{REFERENCES}

1. World Health Organization. World health statistics 2017: monitoring health for the SDGs, Sustainable Development Goals [Internet]. Genebra, Suíca: World Health Organization; 2017 [cited 2019 Apr 2]. Available from: https://apps.who.int/iris/bitstream/hand le/10665/255336/9789241565486-eng.pdf;jsessionid=6CB44346B788EF3881B8D126D5BDBBF4?sequence=1

2. GBD 2016 Alcohol Collaborators. Alcohol use and burden for 195 countries and territories, 1990-2016: a systematic analysis for the Global Burden of Disease Study 2016. Lancet. 2018;392(22):1015-35. doi: 10.1016/S0140-6736(18)31310-2

3. Kachani AT, Brasiliano S, Hochgraf PB. O impacto do consumo alcoólico no ganho de peso. Rev Psiquiatr Clín[Internet]. 2008 [cited 2019 Apr 2];35(suppl1):21-4. Available from: http://www.scielo.br/pdf/rpc/v35s1/a06v35s1.pdf

4. Traversy G, Chaput JP. Alcohol Consumption and Obesity: An Update. Curr Obes Rep. 2015;4(1):122-30. doi: 10.1007/s13679-014-0129-4

5. Fazzino TL, Fleming K, Sher KJ, Sullivan DK, Befort C. Heavy drinking in young adulthood increases risk of transitioning to obesity. Am J Prev Med. 2017;53(2):169-75. doi: 10.1016/j.amepre.2017.02.007

6. Poppitt SD. Beverage Consumption: Are Alcoholic and Sugary Drinks Tipping the Balance towards Overweight and Obesity? Nutrients. 2015;7(8):6700-18. doi: 10.3390/nu7085304

7. National Institute on Alcohol Abuse and Alcoholism. Drinking Levels Defined [Internet]. 2015 [cited 2019 Apr 2]. Available from: https:// www.niaaa.nih.gov/alcohol-health/overview-alcohol-consumption/moderate-binge-drinking

8. Kanny D, Naimi TS, Liu Y, Lu H, Brewer RD. [Annual Total Binge Drinks Consumed by U.S. Adults, 2015]. Am J Prev Med. 2018;54(4):486-96. doi: 10.1016/j.amepre.2017.12.021.

9. Ministério da Saúde (BR). Vigitel Brasil 2018: vigilância de fatores de risco e proteção para doenças crônicas por inquérito telefônico: estimativas sobre frequência e distribuição sociodemográfica de fatores de risco e proteção para doenças crônicas nas capitais dos 26 estados brasileiros e no Distrito Federal em 2018[Internet]. Brasília: Ministério da Saúde; 2019 [cited 2019 Sep 23]. Available from: https:// portalarquivos2.saude.gov.br/images/pdf/2019/julho/25/vigitel-brasil-2018.pdf

10. Chakraborty S. Analysis of NHANES 1999-2002 data reveals noteworthy association of alcohol consumption with obesity. Ann Gastroenterol [Internet]. 2014 [cited 2019 Apr 2];27(3):250-7. Available from: https://www.ncbi.nlm.nih.gov/pmc/articles/PMC4073022/pdf/ AnnGastroenterol-27-250.pdf

11. World Health Organization. Obesity and overweight [Internet]. Genebra: World Health Organization; 2018 [cited 2019 May 2]. Available from: http://www.who.int/news-room/fact-sheets/detail/obesity-and-overweight

12. Gomes Domingos AL, Silva Miranda AE, Pimenta AM, Hermsdorff HHM, Oliveira FLP, Santos LC, et al. Cohort Profile: The Cohort of Universities of Minas Gerais (CUME). Int J Epidemiol. 2018:1-10. doi: 10.1093/ije/dyy152

13. von Elm E, Altman DG, Egger M, Pocock SJ, Gotzsche PC, Vandenbroucke JP. The Strengthening the Reporting of Observational Studies in Epidemiology (STROBE) Statement: guidelines for reporting observational studies. J Clin Epidemiol. 2008;61 (4):344-349. doi: 10.1016/j. jclinepi.2007.11.008

14. Schmidt MI, Duncan BB, Mill JG, Lotufo PA, Chor D, Barreto SM, et al. Cohort profile: Longitudinal Study of Adult Health (ELSA-Brasil). Int J Epidemiol. 2015;44(1):68-75. doi: 10.1093/ije/dyu027

15. Henn RL, Fuchs SC, Moreira LB, Fuchs FD. [Development and validation of a food frequency questionnaire (FFQ-Porto Alegre) for adolescent, adult and elderly populations from Southern Brazil]. Cad Saúde Pública.2010; 26(11):2068-79. DOI: 10.1590/S0102-311X2010001100008.

16. Miranda AES, Ferreira AVM, Oliveira FLP, Hermsdorff HHM, Bressan J, Pimenta AM. Validation of metabolic syndrome and its self reported components in the CUME study. Rev Min Enferm 2017;21:e1069. doi: 10.5935/1415-2762.20170079

17. World Health Organization. Global recommendations on physical activity for health [Internet]. Genebra: World Health Organization; 2010 [cited 2019 May 2]. Available from: https://apps.who.int/iris/bitstream/handle/10665/44399/9789241599979_eng.pdf?sequence=1

18. Souza Lopes AC, Caiaffa WT, Mingoti SA, Lima-Costa MFF. Ingestão alimentar em estudos epidemiológicos. Rev Bras Epidemiol. 2003;6(3):209-19. doi: 10.1590/S1415-790X2003000300004

19. Núcleo de Estudos e Pesquisas em Alimentação. Tabela Brasileira de Composição de Alimentos [Internet]. Campinas, Brasil: Universidade Estadual de Campinas; 2011 [cited 2019 May 2]. Available from: http://www.nepa.unicamp.br/taco/contar/taco_4_edicao_ampliada_e_ revisada.pdf?arquivo=taco_4_versao_ampliada_e_revisada.pdf

20. United States Department of Agriculture - USDA. USDA Food Composition Databases. National Nutrient Database for Standard Reference Release[Internet]. 2018 [cited 2019 May 2]. Available from: https://ndb.nal.usda.gov/ndb/foods

21. Monteiro CA, Cannon G, Moubarac JC, Levy RB, Louzada MLC, Jaime PC. The UN Decade of Nutrition, the NOVA food classification and the trouble with ultra-processing. Public Health Nutr. 2018;21(1):5-17. doi: 10.1017/S1368980017000234

22. Willett WC, Colditz GA. Approaches for conducting large cohort studies. Epidemiol Rev. 1998;20:91-9. doi: 10.1093/oxfordjournals.epirev. a017975

23. Pham CV, Tran HTD, Tran NT. Alcohol consumption and binge drinking among adult population: evidence from the CHILILAB health and demographic surveillance system in Vietnam. J Public Health Manag Pract. 2018;Suppl 2:S67-S73. doi: 10.1097/PHH.0000000000000733 
Binge drinking and overweight in brazilian adults - CUME Project

24. Bartoli F, Carretta D, Crocamo C, Schivalocchi A, Brambilla G, Clerici M, et al. Prevalence and correlates of binge drinking among young adults using alcohol: a cross-sectional survey. Biomed Res Int.2014;2014:1-7. doi: 10.1155/2014/930795

25. Lawental M, Kipnis A, Rigg K. Binge drinking among young adults in Israel: application of the theory of planned behavior. Psy Health Med. 2018;23(9):1060-68. doi: 10.1080/13548506.2018.1467025

26. O'Donovan G, Stamatakis E, Hamer M. Associations between alcohol and obesity in more than 100000 adults in England and Scotland. Br J Nutr. 2018;119(2):222-7. doi: 10.1017/S000711451700352X

27. Peltzer K, Pengpid S. Prevalence, risk awareness and health beliefs of behavioural risk factors for cardiovascular disease among university students in nine ASEAN countries. BMC Public Health. 2018;18:237. doi: 10.1186/s12889-018-5142-1

28. Krieger $\mathrm{H}$, Young $\mathrm{CH}$, Anthenien $\mathrm{AM}$, Neighbors $\mathrm{C}$. The epidemiology of binge drinking among college-age individuals in the United States. Alcohol Res [Internet]. 2018 [cited 2019 Apr 2];39(1):23-30. Available from: https://www.ncbi.nlm.nih.gov/pmc/articles/PMC6104967/pdf/ arcr-39-1-e1_a04.pdf

29. Lima NP, Horta BL, Motta JVDS, Valença MS, Oliveira V, Santos TV, et al. Evolution of overweight and obesity into adulthood, Pelotas, Rio Grande do Sul State, Brazil, 1982-2012. Cad Saude Publica. 2015;31(9):2017-25. doi: 10.1590/0102-311X00173814

30. Bes-Rastrollo M, Pérez Valdivieso JR, Sánchez-Villegas A, Alonso A, Martínez-González MA. Validación del peso e índice de masa corporal auto-declarados de los participantes de una cohorte de graduados universitarios. Rev Esp Obes [Internet]. 2005 [cited 2019 Apr 2];3:183-89. Available from: https://www.unav.edu/documents/16089811/17737790/validacion_peso.pdf

31. Faleiro JS, Giatti L, Barreto SM, Camelo LV, Griep RH, Guimarães JMN, et al. Lifetime socioeconomic status and health-related risk behaviors: the ELSA-Brazil study. Cad Saude Publica. 2017;33(3):e00017916. doi: 10.1590/0102-311x00017916

32. Åhlin J, Hallgren $\mathrm{M}$, Öjehagen $\mathrm{A}$, Källmén $\mathrm{H}$, Forsell Y. Adults with mild to moderate depression exhibit more alcohol related problems compared to the general adult population: a cross sectional study. BMC Public Health. 2015;15:542. doi: 10.1186/s12889-015-1837-8

33. Lourenço S, Oliveira A, Lopes C. The effect of current and lifetime alcohol consumption on overall and central obesity. Eur J Clin Nutr. 2012; 66(7):813-8. doi: 10.1038/ejcn.2012.20 